Vol. 12 (2003): 67-81.

\title{
Conceptualising the economics of plant health protection against invasive pests
}

\author{
Jaakko Heikkilä and Jukka Peltola \\ MTT Agrifood Research Finland, Economic Research, Luutnantintie 13, FIN-00410 Helsinki, Finland, \\ e-mail: jaakko.heikkila@mtt.fi
}

\begin{abstract}
Threats to animal and plant health by invading organisms are increasing due to trade liberalisation and increased movement of goods and people. This paper conceptualises an economic approach to protecting plant health against invasive organisms, specifically addressing a multidisciplinary audience involved in plant health research and in governmental policy-making process. We discuss the conceptual framework and present some generally available management options. We also build a basic model dealing with pre-emptive and reactive control, followed by a numerical illustration to the case of Colorado potato beetle in Finland.

The analysis undertaken supports the notion that pre-emptive control is a viable strategy. Reactive control should be considered only if very low invasion magnitude combines with a low level of damage. However, the strategy choice implies also distributional impacts that warrant attention. The analysis results in a solution for a given set of numbers only. Uncertainty is incorporated through sensitivity analysis. The approach presented demonstrates the basic economic thinking behind the issue, and the concepts described allow further development of more sophisticated forms of analysis.
\end{abstract}

Key words: pests, invasion, plant protection, pest control, Leptinotarsa decemlineata

\section{Introduction}

Invasions by exotic organisms are on the increase due to trade liberalisation and increased movement of goods and people. The topic is not trivial. Globally, 480,000 non-native species have been introduced to various ecosystems, and the annual losses due to non-native organisms in just six countries (the US, the UK, Australia, South

\begin{abstract}
Africa, India and Brazil) are estimated to be a minimum of US\$ 314 billion (Pimentel et al. 2001). Global losses in agriculture to introduced species are estimated at US\$ 55-248 billion annually (Bright 1999).

Besides the sizeable economic losses, the public good nature of invasive species management calls for a social role in managing the problem. The problem arises as protection, once provided, is available for all parties and any one
\end{abstract}




\section{AGRICULTURAL AND FOOD SCIENCE IN FINLAND}

Heikkilä, J. \& Peltola, J. The economics of plant health protection and invasive pests

party's use does not reduce the amount of protection enjoyed by the other parties. Such goods are typically under-provided by the free market.

In strict economic terms, a system aiming to prevent the invasion and/or the establishment of an invasive species (henceforth called 'pre-emptive control' or 'protection system') is appropriate only if protection is achieved in a cost-minimising manner. Another available option is reactive control once the invasion has taken place.

The goal in our study is to conceptualise an economic approach to protecting plant health against invasive organisms and to illustrate it in a numerical simulation, specifically addressing a multidisciplinary audience involved in plant health research and in governmental policy-making process. The outline of the paper is as follows. The next section discusses the conceptual framework and presents some general management options. Then, a basic model dealing with two alternative strategies is built, followed by an application to the case of Colorado potato beetle (Leptinotarsa decemlineata) (CPB) in Finland. The last section discusses the results and concludes.

\section{The conceptual framework}

There is a growing literature on invasive species management. Let it suffice here to note a few examples of how the case has been approached. The classic book by Baumol and Oates (1988) sets the economic basis for analysing the problem of biological pollution in the context of environmental policy. The specific economic policy problem posed by invasive species has been discussed in e.g. Dalmazzone et al. (2000), Perrings et al. (2002) and Horan et al. (2002).

The economic issues related to invasive pest quarantine policies are discussed in Mumford (2002). Given the uncertainties regarding the probability of an invasion, Smith et al. (1999) discuss when to follow the advice given by a screening system, and Thomas and Randall (2000) apply a principal-agent model to deal with the control of intentional introductions. Recent case study applications include Knowler and Barbier (2000) in an aquatic context, Settle et al. (2002) in ecological and Hoddle et al. (2003) in agricultural setting. Our empirically driven case is in approach similar to the analysis of Karnal bunt of wheat by Kelly et al. (2002). Despite the extensive complexities inherent in the problem, we advocate 'doing it simply' when possible. The management question may after all be conceptually very simple: should the pest be prevented from invading and establishing?

\section{Pre-emptive vs. reactive control}

A pest invasion is analogous to a case in which input productivity suddenly declines: less output is produced per each unit of input. To maintain production at a given level more inputs per unit of output need to be used, and since the input has a positive cost, the costs of production increase. Invasion events can be thought of as two states: the event of no invasion corresponds to a state where the pest is prevented from invading and establishing, and the event of increased input use to a state where the pest is controlled if it invades.

The broadest division of invasive species management is thus between pre-emptive and reactive control. Pre-emptive control is here understood as actions taken to maintain vigilance regarding possible invasion events and, if found, totally eradicate the species. Reactive control in turn is understood as producer application of control. Dalmazzone et al. (2000) and Perrings et al. (2002) discuss loosely the same issue and point out that whereas prevention (they call it mitigation) aims to reduce the likelihood of invasion, reactive control aims to reduce the impact of an invasion. In other words, should there be a system (institution or instrument) that aims to reduce the likelihood of entry and/or estab- 
Vol. 12 (2003): 67-81.

lishment of the invasive organism, or should resources be devoted to reactive control if and when it invades in order to reduce the impact of the invasion. This is in essence a proactive versus reactive division.

The division we have made is just one of many possible categorisations. ELI (2002) divides US state-level legislative tools to five categories: i) prevention; ii) regulation; iii) control and management; iv) enforcement and implementation; and v) co-ordination. Our 'pre-emptive control' corresponds to their 'prevention', whereas our 'reactive control' is in their 'control and management' category.

An example of the pre-emptive approach is the European Union (EU) system of protected zones ( $\mathrm{ZP}$, zone protégée) which aims to prevent the introduction and spread of organisms harmful to agricultural production. Under the system it is permissible to import agricultural products associated with the harmful organism into a protected zone only from another protected zone or from a designated buffer zone. The system also requires eradication of quarantine pests if they are found within the protected zone. Pre-emptive control in this paper deals mainly with reducing the likelihood of establishment through eradication, as in our case study there is not much that can be done to prevent the wind-borne invasion events per se.

Actions involved in preventing a pest from invading and establishing are nonetheless costly (surveillance, labelling, import restrictions, eradication, compensation, post-monitoring). Often the benefits of not having the pest around outweigh these costs, but this is by no means inevitable (Mumford 2002). Several countries have voluntarily renounced their EU protected zone, including the UK (except for Northern Ireland) for beet necrotic yellow vein virus, France for maritime pine bast scale (Matsucoccus feytaudi) and Denmark for tomato spotted wilt tospovirus and tobacco whitefly (Bemisia tabaci) (European Commission 2000, EU 2002). Economic factors are likely to have influenced these decisions.

In addition to giving protection against inva- sive organisms, protection systems may also act as technical barriers to trade and as such potentially give the areas concerned a trade advantage. Recently, concern was voiced regarding this issue by Australia in the COP-6 meeting of the parties to the UN Biodiversity Convention (ICTSD 2002).

We see at least four factors that affect the relative effectiveness of pre-emptive versus reactive control. First, the environmental conditions are important in determining how likely the species is to invade, establish and survive the winter conditions. Second, the means of dispersal are important. If there are clear pathways for dispersal, preventative actions can be targeted at key sites. If, on the other hand, wind is the primary means of dispersal, prevention of establishment rather than entry becomes important. Third, whether the species threatens production environment or natural environment matters. For instance agricultural producers are used to regulations, and relatively reliably undertake preventative measures as required. The case is different in natural ecosystems. Fourth, the production structure matters. Professional producers can be expected to act according to regulations, whereas those who produce only for own consumption may be more difficult to educate and persuade to comply.

We agree that in many occasions preventative actions are a good strategy, given the difficulties in eradicating most invasive species reactively. However, it should be noted that in the case of protected zones it is pre-emptive, not reactive, control that requires eradication. We argue that we should not take for granted that one of the strategies is by necessity superior. As shown by Lichtenberg and Penn (2003), prevention is not always the most cost-efficient strategy in the case of agricultural pollution. In addition, international agreements (such as the World Trade Organisation Agreement on Sanitary and Phytosanitary Measures) often require an analysis of the problem at hand to justify any trade restrictive practices. This type of a study helps identifying the factors that are important in determining the strategy choice. 
Heikkilä, J. \& Peltola, J. The economics of plant health protection and invasive pests

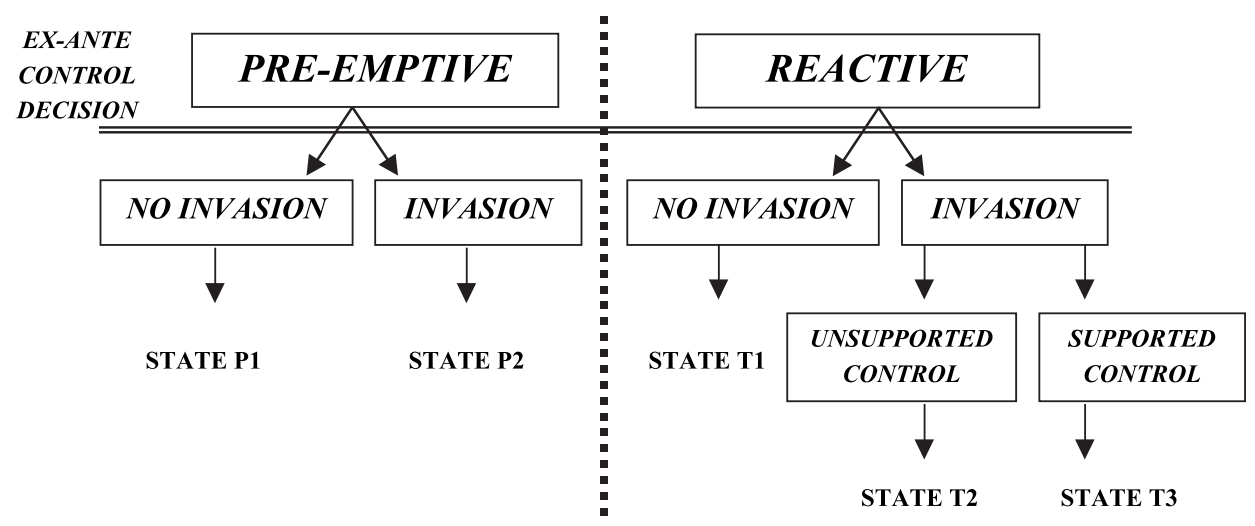

Fig. 1. The two strategies (pre-emptive and reactive control) available for the society and the resulting outcomes.

\section{Pathways, costs and distribution}

Even in pre-emptive versus reactive control framework there are various pathways that may occur. Our framework consists of two simple strategies. The first is to invest resources to prevent the pest from invading and establishing in the first place. The second strategy alternative is to ignore pre-emptive actions, let the pest invade if it so happens and let the producers adapt to the pest's presence. These two strategies may lead to five potential outcomes and thus five cost and benefit structures. The potential paths are presented in Fig. 1.

We assume that whenever the pre-emptive strategy is chosen, establishment can be prevented in all cases, leading to either State P1 or State $\mathrm{P} 2$ in terms of Fig. 1. By doing this we rule out a combination of the two strategies, where resources are invested concurrently in both pre-emptive and reactive control. In our case pre-emptive control consists mainly of authority driven eradication events in the case of an invasion and of maintaining the appropriate organisation in the non-invasion times. Hence it is either the plant protection authority eradicating any outbreaks, or the management is left entirely to producers thus giving up the goal of eradication. The same conclusion in the case of $\mathrm{CPB}$ is reached by Mumford et al. (2000), who note that "there are few alternatives to the two policy options of: i) exclusion (with eradication of outbreaks) [and] ii) abandoning exclusion and relying on grower routine management and control".

In pre-emptive control, if there is no invasion only the fixed costs of pre-emptive actions ensue (State P1). If there is an invasion, also the invasion magnitude dependent variable costs ensue (State $\mathrm{P} 2$ ). In reactive control, there are no ex-ante costs, and thus the ensuing costs will be zero in the case of no invasion (State T1). If there is an invasion, the society may choose to either remain passive (State T2) or to support the producers (State T3). The difference between supported and unsupported control is the effectiveness of control: the producer control is assumed to be more effective when supported by the society. Society supported control can also be thought of as a means of distributing the economic impact of the pest from the producers to the society. In this paper we deal only with unsupported reactive control.

Strategy choice affects the distribution of income through the product output price, which may differ depending on whether there is an invasion or not. Prices depend on the total quantity produced and on the price elasticity of demand, which measures the extent to which the price responds to changes in the total quantity. For instance, in our case exogenous yield shocks 
Vol. 12 (2003): 67-81.

affect the price such that a $15 \%$ decrease in the quantity supplied increases the price by $30 \%$. Price changes are likely if the aggregate output changes sufficiently and international price transfers are imperfect. Hence, despite increased production costs, aggregate profit in the invaded state may turn out to be higher than in the non-invaded state.

However, the pest induced reduction in supply also results in changes in the division of income. First, some producers may lose their entire crop, whereas others escape unharmed. In such a case, the division of profits between the producers ends up being very unequal. Second, the price increases may increase producer profits, while at the same time they reduce consumers' surplus. Consumer surplus measures the additional satisfaction on top of the price gained from consuming the good. If you were willing to pay $€ 10$ for a good that only costs $€ 7$, you gain an extra $€ 3$ of satisfaction. Consumer surplus measures these net benefits of consumption. This is illustrated in a standard supply and demand framework in Fig. 2.

The supply (demand) curve depicts the quantity supplied (demanded) at each price level of the agricultural product. Invasion induces a leftward shift in the supply curve: at each price level less is supplied as production costs have increased. As a result consumer surplus is reduced from area A $+B+C+D$ to just A. Supply change thus results in the consumers losing $\mathrm{B}+\mathrm{C}+\mathrm{D}$ in consumer surplus. The effect on producers is ambiguous, as they lose $F+G$, but gain $B$ in producer surplus (definition analogous to consumer surplus). Hence, whereas the consumers unambiguously lose in the case of an invasion, for the producers the sign of the change depends on the damage magnitude and the price elasticity of demand.

The policy choice thus has economic and distributional implications. In the case of successful pre-emptive control, the cost is simply the cost of the protection system. We assume that the level of protection and hence its cost are determined by the invasion magnitude, resulting in a given $(100 \%)$ probability of success in prevent-

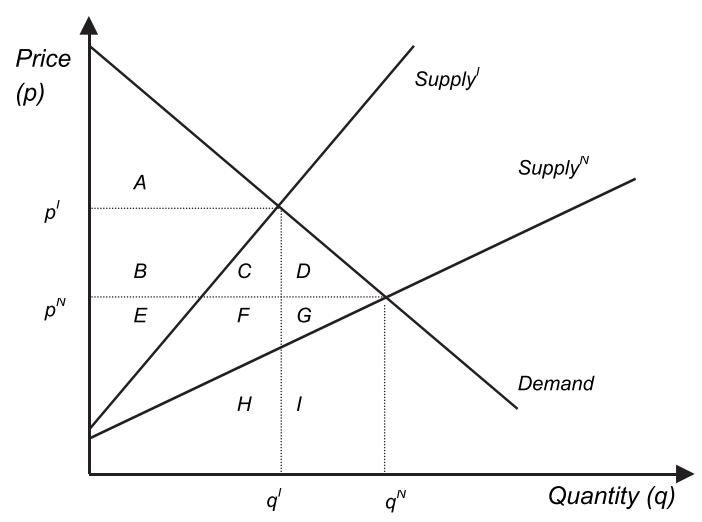

Fig. 2. Demand and supply of an agricultural product with $\left(\right.$ Supply $\left.{ }^{\mathrm{I}}\right)$ and without $\left(\right.$ Supply $\left.^{\mathrm{N}}\right)$ the pest invasion. The original pre-invasion equilibrium is at $\mathrm{p}^{\mathrm{N}}, \mathrm{q}^{\mathrm{N}}$ and the post-invasion equilibrium at $\mathrm{p}^{\mathrm{I}}, \mathrm{q}^{\mathrm{I}}$.

ing the establishment. In the case of reactive control there are three types of costs. First, there are changes in producer surplus due to price changes, pest control costs and the value of lost production, caused by control not being perfectly effective and/or interim damage occurring before control is applied. The second cost incurs as consumers lose some of their consumer surplus if product prices increase. The third type of cost includes the external, off-farm, costs of control, due for instance to environmental impacts of chemical control substances.

\section{Modelling the problem}

\section{The model}

Pest impacts can be modelled from a variety of viewpoints. Ecological approach includes for instance predator-prey, parasitoid-host and epidemiological models. In management side, extensive analysis has dealt with optimal pesticide use, biological pest control and integrated pest management. These studies do not necessarily include both economic and policy considera- 


\section{AGRICULTURAL AND FOOD SCIENCE IN FINLAND}

\section{Heikkilä, J. \& Peltola, J. The economics of plant health protection and invasive pests}

tions. In our opinion both are necessary: the economic component to provide the formal structure, and the policy component to address the costs and benefits of various alternatives. A suitable model could thus consist of pest invasion dynamics and ecophysiology of crop production, which together produce a yield-loss model. The producer's objective function can incorporate this as a damage function. Finally, the farm level objective function should allow aggregation to social level and thus policy analysis.

Our approach is loosely based on a pollution model by Barrett and Segerson (1997), supplemented by a producer's objective function with an incorporated damage function. The approach is in principle similar to that of Knowler and Barbier (2000), except that our model is static: at the beginning of a year a decision is made as to how to control the invasion. We feel the approach is appropriate provided that the invasive pest is not able to establish a permanent population and that damage is not carried over to the following years (crops are annuals). In the case of Colorado potato beetle in Finland both conditions are met, as long as the harsh Finnish winter exterminates all the beetles. Once this is no longer the case, a dynamic approach taking into account the winter survival and development of resistance to chemical control becomes necessary. This will be explored in future work.

The assumptions of the model are as follows: only two alternative strategies are available; the pre-emptive strategy is $100 \%$ effective; control is only damage reducing, not production enhancing; neither strategy has any external costs or benefits; the producers are profit maximisers; the society is a risk neutral cost minimiser; the producers take the price as given, but the price can depend on the state; and the pest is host-specific and causes no ecological damage other than that to its host.

The society has to make a management choice between the following two alternative strategies.

Pre-emptive control: $E\left(T C_{P R E}\right)=A_{F}+A_{V}\left(P_{E}\right)$

Due to uncertainty regarding the magnitude of the pest invasion, it is appropriate to talk about expected total costs (E(TC)). These consist simply of the fixed costs of pre-emptive control $\left(\mathrm{A}_{\mathrm{F}}\right)$ and the variable costs of pre-emptive control $\left(A_{V}\right)$. The latter depend on the expected magnitude of the invasion $\left(\mathrm{P}_{\mathrm{E}}\right)$, which measures the share of production hectares affected (with $\partial \mathrm{A}_{\mathrm{V}} /$ $\left.\partial \mathrm{P}_{\mathrm{E}}>0\right)$.

Reactive control: $E\left(T C_{R E A C}\right)=\Delta P S+\Delta C S+L(2)$

The expected total costs consist of the expected change in producer surplus $(\Delta \mathrm{PS})$ plus the expected change in consumer surplus $(\Delta C S)$ plus the off-farm costs of control (L), which are ignored in the empirical analysis.

The change in producer surplus is estimated by $P_{E} \sum_{i=1}^{N}\left(\Delta \pi_{i}\right)$, i.e. the change in aggregate profit (sum of $\Delta \pi_{\mathrm{i}}$ over $\mathrm{N}$ producers), multiplied by the expected magnitude of the invasion. The change in profit from the 'no invasion' to the 'invasion' state for a representative producer $i$ is

$$
\begin{aligned}
& \Delta \pi_{i}=\pi_{i}^{N O I N V}-\pi_{i}^{I N V} \\
& \text { where } \\
& \begin{aligned}
\pi_{i}^{N O I N V}= & m_{i}\left\{p_{\text {NOINV }} q_{i}\left(x_{i}\right)-p_{x} x_{i}\right\} \\
\pi_{i}^{I N V}= & m_{i}\left\{p_{I N V} q_{i}\left(x_{i}\right)\left[1-D_{i}\left(N_{i}(\theta)-\eta z_{i}\right)\right]-\left[p_{x} x_{i}\right.\right. \\
& \left.\left.+p_{z}(T) z_{i}\right]\right\}
\end{aligned}
\end{aligned}
$$

The quantities are in per hectare terms and the per hectare profit is multiplied by the producer's total production area $\left(\mathrm{m}_{\mathrm{i}}\right)$ to give total profit $\pi_{\mathrm{i}}$ ). The above functions can be broken down as follows.

Production revenue is represented by $p_{s} q_{i}\left(x_{i}\right)$, i.e. the state-dependent producer price of the product $\left(\mathrm{p}_{\mathrm{S}}\right.$, where $\mathrm{S}=$ NOINV or INV) multiplied by the quantity produced $\left(\mathrm{q}_{\mathrm{i}}\right)$ which depends on inputs $\left(\mathrm{x}_{\mathrm{i}}\right)$ (with $\partial \mathrm{q}_{\mathrm{i}} / \partial \mathrm{x}_{\mathrm{i}}>0$ ). The price depends on the magnitude of invasion and the damage that has occurred.

The pest damage function is $D_{i}\left(N_{i}(\theta)-\eta z_{i}\right)$. The magnitude of damage $\left(D_{i}\right)$ depends on the density of pest individuals in the production area 
Vol. 12 (2003): 67-81.

$\left(\mathrm{N}_{\mathrm{i}}\right.$, with $\left.\partial \mathrm{D}_{\mathrm{i}} / \partial \mathrm{N}_{\mathrm{i}}>0\right)$. $\theta$ describes the impact of unknown environmental characteristics on $\mathrm{N}_{\mathrm{i}}$ (with $\partial \mathrm{N}_{\mathrm{i}} / \partial \theta$ unknown). $\mathrm{N}_{\mathrm{i}}$ is reduced by the number eradicated by the producer $\left(\eta z_{i}\right)$, where $z_{i}$ is the magnitude of producer control and $\eta$ is its effectiveness (with $\eta, \mathrm{z}_{\mathrm{i}} \geq 0, \partial \mathrm{D}_{\mathrm{i}} / \partial \eta<0, \partial \mathrm{D}_{\mathrm{i}} / \partial \mathrm{z}_{\mathrm{i}}<0$ ). Damage is proportional to the quantity produced in the absence of the pest, and is presented as a figure between 0 and 1 . In the 'no invasion' case, the damage function is naturally zero.

Production costs are represented by $p_{x} x_{i}+p_{z}(T) z_{i}$. The first term denotes the production costs in the absence of the pest, i.e. the unit price of inputs $\left(\mathrm{p}_{\mathrm{x}}\right)$ multiplied by their quantity $\left(\mathrm{x}_{\mathrm{i}}\right)$. The second term is the magnitude of control $\left(\mathrm{z}_{\mathrm{i}}\right)$ multiplied by its unit price $\left(\mathrm{p}_{\mathrm{z}}\right)$, which can be subsidised by the society (T) (with $\partial \mathrm{p}_{\mathrm{z}}$ I $\partial \mathrm{T}<0)$. In the 'no invasion' -case the second term is zero. We have expressed $\mathrm{T}$ to be manifested through the price of control, i.e. if the society chooses to support control $(\mathrm{T}>0)$, the price of control to producers is lowered, and relatively more of it will be undertaken. It is also possible that the society support operates through the effectiveness of control $\eta(T)$ or the magnitude of control $\mathrm{z}_{\mathrm{i}}(\mathrm{T})$. In the empirical case we assume the society does not support reactive control, and thus we leave this issue open here.

The expected change in consumer surplus is estimated by

$$
\begin{aligned}
\Delta C S= & P_{E}\left(p_{I N V}-p_{N O I N V}\right) \sum_{i=1}^{N}\left(m_{i} q_{i}\right)\left[\left(1-P_{E} D\right)\right. \\
& \left.+\frac{P_{E} D}{2}\right] .
\end{aligned}
$$

This expression corresponds to area $\mathrm{B}+\mathrm{C}+$ $\mathrm{D}$ in terms of Fig. 2. In essence it represents the losses experienced by the consumers due to invasion induced commodity price increase and reduced supply.

\section{Choice criteria}

The society as a whole encounters costs when managing the problem. As we concentrate on comparing the two mutually exclusive strategies, we prefer to keep the discussion non-technical. For technical consideration, see e.g. Barrett and Segerson (1997). Four potential social objectives are: i) minimise unconstrained total costs; ii) minimise expenditure subject to a given level of damages; iii) minimise damage subject to available funds; and iv) minimise the cost difference between invasion and no invasion years. Not wanting to artificially define standards for damage, expenditure or variability, we find the basic criterion of unconstrained cost minimisation a reasonable one to use. Nonetheless, it is worth pointing out that even this basic framework allows consideration of various objectives.

Adopting the first objective, the problem of the risk neutral and welfare maximising society is to choose $\min \left\{E\left(T C_{P R E}\right), E\left(T C_{R E A C}\right)\right\}$. The variables on which the choice depends are

i) the damage done by the pest (D);

ii) the expected invasion magnitude $\left(\mathrm{P}_{\mathrm{E}}\right)$;

iii) the cost of the protection system $(\mathrm{A})$;

iv) the cost of reactive control $\left(\mathrm{p}_{\mathrm{z}} \mathrm{z}_{\mathrm{i}}\right)$; and

v) the price elasticity of demand, as this determines $\mathrm{p}_{\text {INV }}-\mathrm{p}_{\mathrm{NOINV}}$.

\section{A numerical illustration}

\section{The empirical case}

We now illustrate an analysis of the two policy alternatives described above. The case we discuss is that of Colorado potato beetle and food potato production in Finland. The beetle has made two larger invasions to Finland, in the summers of 1998 and 2002, but has not survived through the winter. More details on the CPB and Finland can be found in Tomminen (1999) or Koukkunen (1999).

The CPB is the most destructive insect defoliator of potato. It is an oligophagous species that feeds exclusively on Solanaceae, primarily on 


\section{Heikkilä, J. \& Peltola, J. The economics of plant health protection and invasive pests}

Solanum species (Raman and Radcliffe 1992). The beetle originates from North America and is nowadays common in Europe except for Fennoscandia, Britain and Ireland. The species has become more destructive in Europe than it is in North America due to a lack of predators, parasites and diseases (Sandhall and Lindroth 1976).

The case follows consistently the assumptions made earlier. External ecosystem damage of invasion would be fairly limited, and as long as the winter exterminates all the beetles, the static approach is justifiable. Finland also has a protection system in force: certain areas have the European Union ZP -status regarding the beetle (EU 2002). These areas include Satakunta, Varsinais-Suomi, Uusimaa, Pirkanmaa, Häme, SouthEastern Finland and the Åland Islands and they represent $30-40 \%$ of total potato production in Finland.

As mentioned at the beginning, pre-emptive control is understood as actions taken to maintain vigilance regarding possible invasion events and, if found, totally eradicate the beetle from Finnish soil. An alternative, reactive control, involves producer application of control (e.g. pesticides), which is not perfectly effective in that crop losses still result. Economic evaluations of
CPB management have not been conducted in Finland, but in the United Kingdom Mumford et al. (2000) estimated the costs of reactive control to be 7.5 times those of prevention (protected zone) over a 30 -year period.

There are two main differences between our case and that of Mumford et al. (2000). First, they assume winter survival, which we have ignored as it has not so far occurred in Finland. Second, they assume there are no crop losses due to the beetle (control is perfectly effective) and thus there are no associated price impacts. We think that especially in marginal conditions such as Finland crop losses are possible despite control, and that since the Finnish potato market is fairly isolated, it is probable that any crop losses result in price increases.

\section{Application}

We assume that there is an invasion of a given magnitude, with zero magnitude implying that there is no invasion. Table 1 presents indicative variable values to apply the model. Given these data, it is a straightforward task to calculate the costs for the two strategies.

Table 1. The illustrative baseline variable values.

\begin{tabular}{|c|c|c|c|}
\hline Variable & Symbol & Value & Figure based on \\
\hline $\begin{array}{l}\text { Cost of pre-emptive control at } \\
\text { invasion magnitude } 0.10 \text {, €/year }\end{array}$ & A & $€ 350,000$ & KTTK estimate of the 2002 invasion. \\
\hline Invasion magnitude, $\%$ & $P_{E}$ & 0.10 & KTTK estimate of the 2002 invasion. \\
\hline Crop damage by the pest, $\%$ & $\mathrm{D}_{\mathrm{i}}$ & 0.15 & $\begin{array}{l}\text { Grafius } 1997 \text { in N. America and } \\
\text { Parkkonen } 2002 \text { in Russia }\end{array}$ \\
\hline Reactive control costs, $€ /$ ha & $\mathrm{p}_{\mathrm{z}} \mathrm{z}_{\mathrm{i}}$ & $200 € / \mathrm{ha}$ & $\begin{array}{l}\text { Grafius 1997, Raman and Radcliffe } \\
\text { 1992. No data for Finland available. }\end{array}$ \\
\hline Production costs, $€ /$ ha & $\mathrm{p}_{\mathrm{x}} \mathrm{x}_{\mathrm{i}}$ & $3,000 € / \mathrm{ha}$ & MKL 1999 \\
\hline Product producer price, $€ / \mathrm{kg}$ & $\begin{array}{l}\mathrm{p}_{\mathrm{S}} \\
(\mathrm{S}= \\
\text { NOINV, } \\
\text { INV) }\end{array}$ & $\begin{array}{l}\mathrm{p}_{\text {NOINV }}= \\
0.20 € / \mathrm{kg} \\
\mathrm{p}_{\text {INV }}= \\
0.26 € / \mathrm{kg}\end{array}$ & $\begin{array}{l}\text { Values are within recent price } \\
\text { fluctuations (MMM 2001). Price } \\
\text { elasticity of demand based on } \\
\text { Jalonoja and Pietola (2001). }\end{array}$ \\
\hline Total production area, ha & & 10,700 ha & MMM 2001 \\
\hline Total production, $\mathrm{kg} /$ year & & $240,700,000 \mathrm{~kg}$ & MMM 2001 \\
\hline
\end{tabular}


Vol. 12 (2003): 67-81.

Table 2. Strategy costs and choice by sector. Shows both absolute (unweighted) and invasion magnitude weighted costs.

\begin{tabular}{|c|c|c|c|c|c|c|}
\hline & \multicolumn{2}{|c|}{ Producers } & \multicolumn{2}{|c|}{ Consumers } & \multicolumn{2}{|c|}{ Aggregate } \\
\hline & Absolute & Weighted & Absolute & Weighted & Absolute & Weighted \\
\hline Pre-emptive control, $€$ & 0 & 0 & $3,230,000$ & 350,000 & $3,230,000$ & 350,000 \\
\hline Reactive control, $€$ & $-2,914,700$ & $-486,437$ & $13,358,850$ & $1,433,368$ & $10,444,150$ & 946,931 \\
\hline Control choice & Reactive & Reactive & Pre-emptive & Pre-emptive & Pre-emptive & Pre-emptive \\
\hline
\end{tabular}

In pre-emptive control, it is assumed that the consumers end up paying the costs of the protection system. In reactive control, consumers suffer a loss of consumer surplus represented by $\mathrm{B}+\mathrm{C}+\mathrm{D}$ in terms of Fig. 2. Producer effects are estimated by area $\mathrm{B}+\mathrm{C}-(\mathrm{G}+\mathrm{I})$, i.e. additional sales at the new price less the lost sales at the old price, from which the additional production costs $(\mathrm{C}+\mathrm{F}-\mathrm{I})$ are subtracted.

The industry is assumed to be in long-run equilibrium prior to the invasion. We also have to make some additional assumptions: i) the past figures on total production as well as on production and control costs are the profit maximising solutions; ii) the demand curve is linear over the price range considered; and iii) the resulting price and quantity combination is the new market clearing equilibrium.

Computing the costs for the two strategies results in the outcome presented in Table 2. In pre-emptive control, the expected total costs are $€ 350,000$ (i.e. the cost of the protection system at $\left.\mathrm{P}_{\mathrm{E}}=0.10\right)$, whereas in reactive control the expected total costs appear to be $€ 946,931$. With these indicative figures, and under our assumptions, it would thus be reasonable to maintain the protected zone.

The preferred choice however depends on the sector we are dealing with. Under this baseline scenario the two sectors have conflicting preferences. Consumers would be in favour of the protection system, as they would suffer consumer surplus losses in the case of reactive control. Producers, however, on aggregate could be bet- ter off under reactive control, as they would possibly see negative costs (gains) through rising prices. Naturally, those who lose their crop would be worse off, but the invasion induced price increases would benefit the rest of the producers. In absolute terms the consumer losses are greater than the producer gains, and if both are given equal weight by the society, the protection system is the cost-minimising strategy.

\section{Sensitivity analysis}

Naturally, these total costs should be thought of merely as a starting point for sensitivity analysis. In this scenario, reactive control becomes attractive if, other things equal, one of the following happens (figures in brackets indicate the change from the baseline calculation):

i) the damage done by the pest decreases to less than $2.78 \%$ ( $81 \%$ decrease);

ii) the invasion magnitude decreases to less than $0.49 \%$ (95\% decrease);

iii) the cost of the protection system increases to more than €946,931 (171\% increase);

iv) the cost of reactive control becomes negative; or

v) the producer price in the invasion state becomes negative.

The last two events are unlikely, but any of the other events are possible. Let us, therefore, explore how isolated deviations in the variables affect the chosen strategy. 
Heikkilä, J. \& Peltola, J. The economics of plant health protection and invasive pests

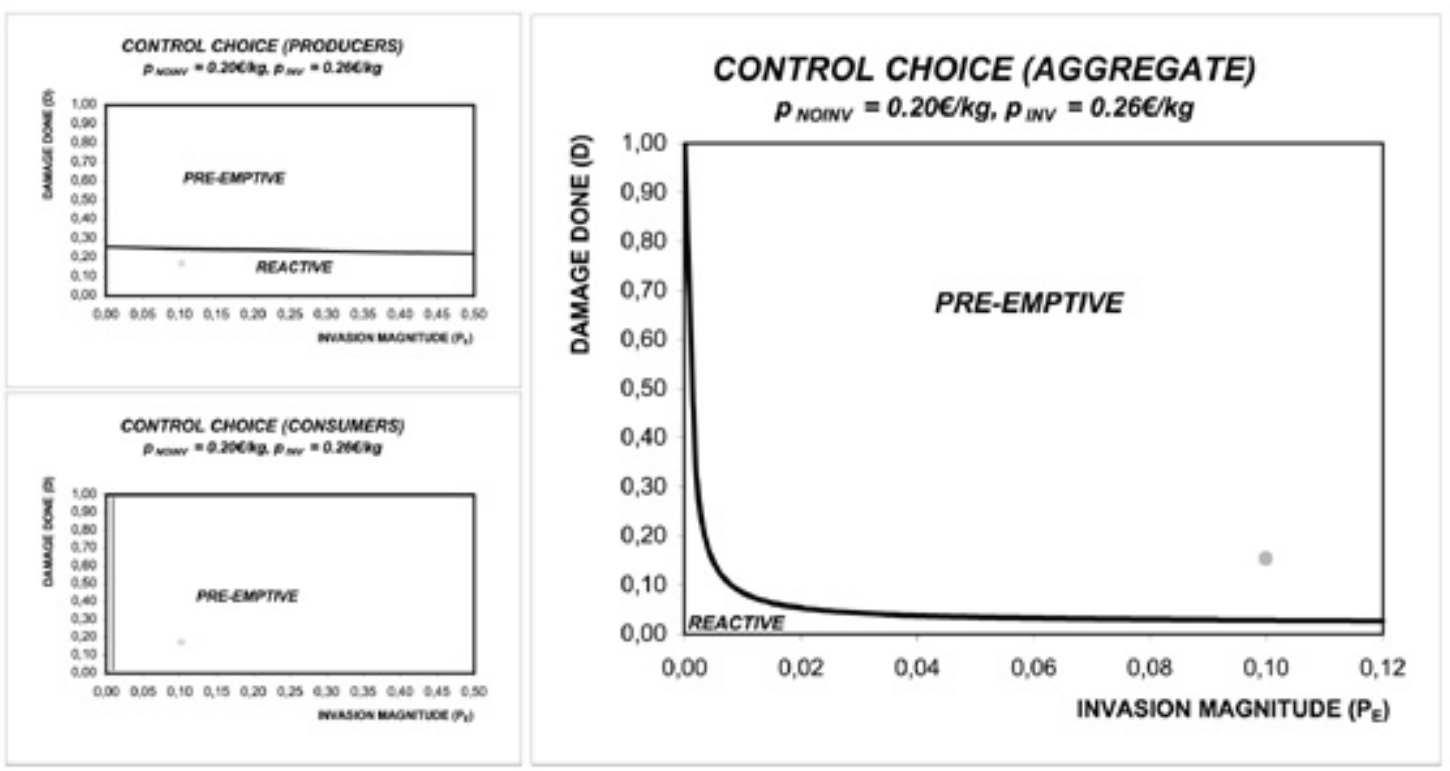

Fig. 3. The choice of strategy depending on damage and invasion magnitude for producers and consumers and on aggregate when both groups are given equal weight. The line is the strategy boundary, i.e. it depicts the points at which both strategies impose the same total costs. Outside this line, one of the strategies (indicated) is preferred. The dot represents the baseline values. Note the truncated $\mathrm{x}$-axis.

\section{Damage and invasion magnitude}

The effect of changes in the proportional damage done and the invasion magnitude are presented in Fig. 3. The diagrams present the strategy chosen at different values of damage and invasion magnitude, i.e. events i) and ii) above combined. All other values are as given in Table 1 .

Producers will always prefer the protection system if the damage done is over $20-25 \%$, no matter what the invasion magnitude. On the contrary, for consumers the choice depends more on the invasion magnitude, and only at a very low level of less than $0.3 \%$ magnitude is reactive control preferred, no matter what the damage. This is because at this level of magnitude the overall price effects remain marginal. For most of the range considered, the preferences of both groups are fairly compatible, but it is notable that the current values (and the most plausible values) are located at a region where the groups have incompatible preferences.
As for the aggregate choice, the right hand side of Fig. 3 shows that both damage done by the pest and the invasion magnitude have to be very low to justify reactive control. Basically, the invasion magnitude cannot be higher than about $1-2 \%$ to justify reactive control. For comparison, the invasion in 2002 resulted in control actions in about $5 \%$ and inspection in about $10 \%$ of the protected zone production area. On the other hand, if the damage done remains below about $2 \%$, reactive control is preferred no matter what the invasion magnitude. In this case, however, the cost of reactive control becomes a critical factor. Thus, in practice only a limited range of low damage and very low invasion magnitude justifies adopting the reactive strategy.

\section{Price response}

In our analysis, a $15 \%$ decrease in yield results in $30 \%$ increase in price, a relationship forwarded by Jalonoja and Pietola (2001) when study- 
Vol. 12 (2003): 67-81.

ing the actual price behaviour of food potato markets in Finland. Price changes affect the distribution of costs and benefits substantially, but they do not seem to have major overall strategy effects. It is fairly evident that the higher the price increase, the more likely the producers are to prefer reactive control, whereas for the consumers it is the opposite. The preferences are compatible for only a limited range of moderate price increases. On aggregate, if the post-invasion price is above about $0.75 € / \mathrm{kg}$, pre-emptive control is preferred regardless of the preinvasion price, since at this level the consumer losses become large relative to the cost of the protection system. Further, it is difficult to see reactive control being preferred in this comparison, as the pre-invasion price would need to be below $0.04 € / \mathrm{kg}$ for reactive control to be preferred.

It was also analysed how the invasion magnitude and damage done have to change to switch the strategy, given a range of price increases. On aggregate, the effect is close to negligible, i.e. no matter what the price increase, the optimal strategy is little affected. However, when looked from the point of view of either of the two groups, the price increase does have a significant effect: quite intuitively the producers like and consumers dislike it. For instance, irrespective of the invasion magnitude, the consumers prefer pre-emptive control whenever the price increase is more than $7-8 \%$, whereas the producers prefer pre-emptive control only when the price increase is below about $20-25 \%$.

If, following the invasion, the price remains unchanged at $0.20 € / \mathrm{kg}$, the pre-emptive strategy is still the cost minimising choice. In such a case, reactive control becomes attractive if, other things equal (figures in brackets indicate the change from the baseline calculation):

i) the damage done decreases to less than $2.83 \%$ ( $81 \%$ decrease);

ii) the invasion magnitude decreases to less than $0.49 \%$ (95\% decrease);

iii) the cost of the protection system increases to more than $€ 936,100$ (167\% increase); iv) the cost of reactive control becomes negative; or

v) the prices at both states decrease to less than $0.04 € / \mathrm{kg}$ ( $80 \%$ decrease).

The situation is basically the same as before. Any invasion induced price increase only makes the case for pre-emptive control stronger.

\section{Costs of the protection system and reactive control} Regardless of whether there is the assumed price increase or not, the cost of reactive control has to decrease such that it becomes negative to change the strategy, whereas the cost of the protection system would have to increase by about $167-171 \%$ to change the strategy. Thus, the cost of control does not seem critical, but the cost of the protection system may in theory increase such that it triggers a strategy switch.

On aggregate, quite naturally, the higher the cost of reactive control, the higher can also the cost of protection be to remain the preferred choice. Again, however, the two sectors have opposite preferences. Producers prefer reactive control - regardless of the cost of protection for as long as the cost of reactive control is less than $655 € /$ ha. Consumers, on the other hand, prefer pre-emptive control - regardless of the cost of reactive control - for as long as the cost of protection is below about $€ 1,400,000$.

This is largely due to our assumptions regarding who pays what. Given that so far we do not have data for reactive control costs in Finland, it is comforting to observe that it is not a critical variable here. However, as was observed earlier, if the damage done is very low, the cost of reactive control, and also the cost of the protection system, may become critical factors in determining the optimal strategy.

\section{Discussion}

Generally, it seems that only when a very low invasion magnitude combines with a low level 


\section{AGRICULTURAL AND FOOD SCIENCE IN FINLAND}

\section{Heikkilä, J. \& Peltola, J. The economics of plant health protection and invasive pests}

of damage is the reactive strategy more attractive than pre-emptive control. All the variables contribute somewhat to this choice, but the cost of reactive control is the least critical of the five variables considered. This is because it is relatively small in absolute terms, the value being only $€ 214,000$ in the baseline scenario, compared to e.g. expected consumer losses of $€ 1.4$ million.

The implication is that the strategy choice cannot be impacted through actions that lower reactive control costs. However, for reasons of effectiveness and cost-efficiency these costs do matter, and should naturally be minimised. This should preferably be done in such a way that all costs of control, including the environmental impacts of chemical control substances, are included in the assessment. Another implication is that if the efficiency of control methods is increased such that damage can be reduced, and at the same time the expected invasion magnitude is reduced through for instance regional co-operation, the case may turn out to be favourable for the reactive strategy.

The cost of pre-emptive control on the other hand influences the choice more, especially when the damage done is low. The assumption of $100 \%$ effectiveness that we made in this paper is naturally very restrictive. In reality, no system is perfectly efficient, and there will be a trade-off situation in two respects: first, more resources spent on pre-emptive control means on one hand that protection becomes more preferable (as it makes it more effective), but on the other hand it becomes less preferable (as it gets more expensive). The second trade-off is that the more protection there is, the more better-off the society is in the sense that invasion and establishment are less likely, but the less well-off it is in the sense that international commerce is restricted to a greater degree. Actual policies dealing with a public good problem such as the present one have to also account for such trade-off problems as well as for various incentives and disincentives of the policies.

Let us yet emphasise that in many occasions preventative actions are a good choice of strate- gy. This approach is forwarded by e.g. the intergovernmental scientific advisory body established by the UN Biodiversity Convention (Perrault and Muffett 2001). Even if the protection system might not succeed in keeping the pest out of the country, it could still reduce the impact of the invasion. However, we argue that no strategy is automatically preferred in all circumstances. Pre-emptive control may not be optimal in cases where there are high costs of pre-emptive control compared to its benefits, or an exogenous factor (such as temperature) automatically eradicating the population at regular intervals. As has been demonstrated, it is not impossible to find plausible variable values that favour reactive control in the case of CPB in Finland.

It is also possible that a protection system is preferred even when reactive control appears to be the cost-minimising strategy. This may be due to additional benefits of protection (or additional costs of reactive control) that have not been considered here. The benefits of the protection system could be for instance enhanced protection of domestic production from imports, and the costs of reactive control could be environmental costs of control. The observed events of countries renouncing their protection systems suggest that either the criterion used or the relative costs and benefits of the strategies have changed.

The strategy choice also has distributional effects. Possible invasion induced price increases unambiguously lead to losses in consumer surplus, and an invasion would also affect the distribution of profits within the producers. Hence in the case of reactive control, the distributional effects depend on whether there is an invasion or not, and on how the price responds to the invasion. The pre-emptive strategy thus does not imply as great distributional impacts, but it too has to be funded by some means. If it is the consumers (taxpayers) that end up paying the bill, they in essence are subsidising the producers. It is interesting to note that the baseline values of Table 1 are all located in a region at which the preferences of the two groups are incompatible. 
Vol. 12 (2003): 67-81.

The overall strategy choice depends on the relative magnitudes of the consumer and producer effects, and how these are weighted. We have assumed similar weights for both groups, but in reality the case may be that one of the groups is given more weight in decision making. It has to be noted, too, that we have assumed the consumers to carry the full costs of the protection system. It can naturally be the case that the producers have to contribute towards these costs in a way or another. A clear conclusion nonetheless is that whether there is an invasion or not is not the only issue to take into account. It is also important to consider how the market environment responds to the shock and how any counter-measures are to be financed.

\section{Conclusions}

The discussion in this paper is presented in a static one-period framework, in which pair-wise changes in the variables are analysed. The analysis results in a solution for a given set of numbers only. Uncertainty is incorporated through sensitivity analysis.

The main outcome of the current analysis is that in most cases jointly organised pre-emptive control is more attractive than reactive control undertaken by the farmers. One of the reasons underlying this may be the public good nature of the problem and the subsequent incentives for organised protection: when the responsibility for protection is left to a single farmer, s/he only needs to account for the potential calamities af- fecting her/his farm alone. When pre-emptive control is the responsibility of a joint body, all costs of a potential outbreak are taken into account more properly.

It cannot be determined by this analysis whether it is the exact form of management (preemptive vs. reactive) or the aggregate level of management (organised joint protection vs. decentralised farm level control) that is the key factor in favouring one management strategy over another. However, a joint approach often requires a government involvement, which may be opposed by some producers. Additionally, even if paid for by the producers themselves, the payment mechanism has to be agreed upon. Such issues may hinder the adoption of jointly organised protection.

In Finland, the CPB population and the damages caused have so far been somewhat limited as the beetles tend to die during the winter, allowing a static approach to evaluating the problem. However, given the ability of the CPB to rapidly develop more strenuous traits and the fact that the invasion pressure in Fennoscandia is increasing, it may become necessary to evaluate these same issues in a dynamic framework accounting for long term costs and benefits.

The current approach has demonstrated the economic thinking behind the issue and highlighted various factors that should be accounted for. The basic concepts described here provide a platform for the development of more sophisticated forms of analysis.

Acknowledgements. The authors wish to express their gratitude to two anonymous referees for their constructive comments.

\section{References}

Barrett, J. \& Segerson, K. 1997. Prevention and treatment in environmental policy design. Journal of Environmental Economics and Management 33: 196213.

Baumol, W.J. \& Oates, W.E. 1988. The theory of envi- ronmental policy. Second Edition. Cambridge: Cambridge University Press. 299 p.

Bright, C. 1999. Invasive species: pathogens of globalization. Foreign Policy 116: 50-64.

Dalmazzone, S., Perrings, C. \& Williamson, M. 2000. 


\section{AGRICULTURAL AND FOOD SCIENCE IN FINLAND}

\section{Heikkilä, J. \& Peltola, J. The economics of plant health protection and invasive pests}

Exotic pests and diseases: an economic perspective. In: Perrings, C. et al. (eds.). The economics of biological invasions. Cheltenham: Edward Elgar. 264 p.

ELI 2002. Halting the invasion: state tools for invasive species management. Washington D.C: Environmental Law Institute. $112 \mathrm{p}$.

EU 2002. EU Commission Directive 2002/28/EC of 19 March 2002 amending certain annexes to Council Directive 2000/29/EC on protective measures against the introduction into the Community of organisms harmful to plants or plant products and against their spread within the Community.

European Commission 2000. Health and consumer protection directorate-general. Report on a mission carried out in Denmark from 4 to 8 September 2000 in order to audit the plant health system in the potato sector. Cited 9 April 2002. Updated 8 April 2003. Available on the Internet: http://europa.eu.int/comm/food/ index_en.html

Grafius, E. 1997. Economic impact of insecticide resistance in the Colorado potato beetle (Coleoptera: Chrysomelidae) on the Michigan potato industry. Journal of Economic Entomology 90: 1144-1151.

Hoddle, M.S., Jetter, K.M. \& Morse, J.G. 2003. The economic impact of Scirtothrips perseae Nakahara (Thysanoptera: Thripidae) on California avocado production. Crop Protection 22: 485-493.

Horan, R.D., Perrings, C., Lupi, F. \& Bulte, E.H. 2002. Biological pollution prevention strategies under ignorance: the case of invasive species. American Journal of Agricultural Economics 84: 1303-1310.

ICTSD 2002. BRIDGES Trade BioRes email newsletter. Vol. 2 No. 8. 2 May, 2002.

Jalonoja, K. \& Pietola, K. 2001. Whole sales market for fresh potatoes in Finland. Agricultural and Food Science in Finland 10: 69-80.

Kelly, P.W., Kinsella, A. \& Brennan, J.P. 2002. Assessing the optimal control policy for a quarantinable plant disease: the case of Karnal bunt of wheat. A poster presented in the 10th EAAE Congress, 28-31 August 2002, Zaragoza, Spain.

Knowler, D. \& Barbier, E.B. 2000. The economics of an invading species: a theoretical model and case study application. In: Perrings, C. et al. (eds.). 2000. The economics of biological invasions. Cheltenham: Edward Elgar. 264 p.

Koukkunen, K. 1999. Warokaa perunakuoriasta! Tieteessä tapahtuu 7/1999. Cited 9 April 2003. Available on the Internet: http://www.tsv.fi/ttapaht/997/ koukkunen.htm

Lichtenberg, E. \& Penn, T.M. 2003. Prevention versus treatment under precautionary regulation: a case study of groundwater contamination under uncertainty. American Journal of Agricultural Economics 85: 44-58.

MKL 1999. Mallilaskelmia maataloudesta. Compiled by
Ari Enroth. Helsinki: Maaseutukeskusten liitto. 51 p. MMM 2001. Yearbook of farm statistics 2001. Helsinki: Ministry of Agriculture and Forestry. 262 p.

Mumford, J.D. 2002. Economic issues related to quarantine in international trade. European Review of Agricultural Economics 29: 329-348.

Mumford, J.D., Temple, M.L., Quinlan, M.M., Gladders P., Blood-Smyth, J.A., Mourato, S.M., Makuch, Z. \& Crabb, R.J. 2000. Economic policy evaluation of MAFF's Plant health programme. Report to Ministry of Agriculture Fisheries and Food, London, United Kingdom. Cited 9 April 2003. Updated 2 August 2002. Available on the Internet: http://www.defra.gov.uk/ esg/economics/econeval/planth/

Parkkonen, M. 2002. Venäjän pelloilla aletaan viljellä tuholaisia tappavaa perunaa. Helsingin Sanomat 26.09.2002. Page C1.

Perrault, A. \& Muffett, W.C. 2001. Encouraging prevention, developing capacity and providing accountability: a strategy for addressing international invasive alien species issues. Center for International Environmental Law Discussion Paper. Washington D.C. $18 \mathrm{p}$.

Perrings, C., Williamson, M., Barbier, E.B., Delfino, D., Dalmazzone, S., Shogren, J., Simmons, P. \& Watkinson, A. 2002. Biological invasions risks and the public good: an economic perspective. Conservation Ecology 6, 1: 1. Cited 9 April 2003. Updated 14 March 2003. Available on the Internet: http:// www.consecol.org/vol6/iss1/art1/

Pimentel, D., McNair, S., Janecka, J., Wightman, J., Simmonds, C., O'Connell, C., Wong, E., Russel, L., Zern, J., Aquino, T. \& Tsomondo, T. 2001. Economic and environmental threats of alien plant, animal, and microbe invasions. Agriculture, Ecosystems and Environment 84: 1-20.

Raman, K.V. \& Radcliffe, E.B. 1992. Pest aspects of potato production: Part 2. Insect pests. In: Harris P. (ed.). 1992. The potato crop: the scientific basis for improvement. Second Edition. London: Chapman \& Hall. 910 p.

Sandhall, A. \& Lindroth, C.H. 1976. Kovakuoriaiset. Porvoo - Helsinki - Juva: WSOY. 94 p.

Settle, C., Crocker, T.D. \& Shogren, J.F. 2002. On the joint determination of biological and economic systems. Ecological Economics 42: 301-311.

Smith, C.S., Lonsdane, W.M. \& Fortune, J. 1999. When to ignore advice: invasion predictions and decision theory. Biological Invasions 1: 89-96.

Thomas, M.H. \& Randall, A. 2000. Intentional introductions of nonindigenous species: a principal-agent model and protocol for revocable decisions. Ecological Economics 34: 333-345.

Tomminen, J. 1999. Koloradonkuoriainen - tuliko meille jäädäkseen? Tuottava peruna 2/1999: 13-15. 
Vol. 12 (2003): 67-81.

\title{
SELOSTUS
}

\section{Tulokastuholaiset ja kasvinsuojelu: taloudellinen näkökulma}

\author{
Jaakko Heikkilä ja Jukka Peltola \\ MTT (Maa- ja elintarviketalouden tutkimuskeskus)
}

Tulokaslajeista aiheutuva uhka lisääntyy kansainvälisen kaupan ja ihmisten liikkumisen kasvun myötä. Tulokaslajien hallinta on kuitenkin julkishyödyke, jolle on tyypillistä, että sen käyttöön voi osallistua ja siitä hyötyä kuka tahansa, ja että lisäkäyttäjät eivät vähennä hyödykkeen arvoa muiden käyttäjien näkökulmasta. Näiden ominaisuuksien vuoksi tulokaslajien hallintaa on vaikea markkinoida, ja asian ratkaisemiseksi tarvitaan usein yhteiskunnan panosta.

Tämä artikkeli hahmottaa kasvituholaisten torjuntapolitiikan suunnittelua ja arvioimista taloustieteen näkökulmasta. Esitämme aluksi muutamia yleisiä vaihtoehtoja tulokaslajistrategiaksi. Yksinkertaistetussa matemaattisessa mallissa on kaksi strategiavaihtoehtoa: ennaltaehkäisy ja reaktiivinen sopeutuminen.
Esitämme myös mallin numeerisen sovelluksen liittyen koloradonkuoriaisen torjuntaan Suomessa.

Analyysin perusteella näyttää siltä, että esimerkkitapauksessa suojajärjestelmä on kustannustehokas strategia. Jälkikäteistä sopeutumista tulisi harkita vain, jos odotettu invaasio ei ole laaja ja tuho on pieni. Strategian valinta vaikuttaa kuitenkin myös tulonjakoon, mihin on syytä kiinnittää huomiota. Lisäksi epävarmuus on usein merkittävä tulokaslajeihin liittyvä tekijä. Tämä artikkeli hahmottaa ongelmaan liittyvää taloudellista ajattelua. Käsiteltyjen konseptien pohjalta on mahdollista suorittaa yksityiskohtaisempia ja todellisuuden paremmin huomioon ottavia laskelmia ja arvioita. 
